Egyptian J. Anim. Prod. (2000) 37 (I): 19-30

\title{
INCLUSION OF GRADED LEVELS OF RICE POLISHINGS IN THE RATIONS OF OSSIMI MALE LAMBS
}

\author{
I.M. Awadalla, Y.A. Maareck, M.I. Mohamed and R.I. El-Kady \\ Department of Animal and Poultry Nutrition and Production, National Research \\ Centre, Cairo, Egypt
}

\section{SUMMARY}

A feeding trail was carried out using 21 Ossimi male lambs, five to six months old, (three groups, seven each) to investigate the effect of inclusion of rice polishings $(R P)$ in the rations to replace 0,30 or $60 \%$ of a conventional concentrate feed mixture. The trial lasted for 16 weeks during which growth performance was studied. At the end of the trial, a digestion trial was conducted with three lambs chosen randomly from each group while the other four lambs were slaughtered to study physical and chemical characteristics of carcass. Daily DM intake increased with $30 \%$ level of RP in the ration while it decreased at $60 \%$ level as compared with the control. Rice polishings inclusion in the rations at $30 \%$ level resulted in similar growth performance and feed conversion (DM, TDN and DCP/unit gain) as compared to the control. On the other hand, RP inclusion at $60 \%$ level resulted in lower weight gain and negatively affected feed conversion (DM, TDN and DCP/unit gain) as compared with the other groups. Dressing perrcentage either based on fasting or empty body weights, kidney and testes weights and chemical analysis of meat of best rib cuts were not affected significantly by treatment. On the other hand, feeding lambs on $60 \%$ level of RP decreased weights of hot carcass, liver, lungs, and each of omentum, kidney and tail fats. It also decreased lean, bone and fat weights of best ribs cuts as compared with the other groups. In view of economic efficiency inclusion of $R P$ in the rations at $30 \%$ level resulted in the highest relative economic efficiency (120\%) as compared with the control or 60\% level (being 100 and $78 \%$, respectively).

Keywords : Lamb, rice polishings, growth, feed conversion, nutrient digestibilities, carcass traits.

\section{INTRODUCTION}

Rice polsihings, a by-product of rice sheller mills is considered a good source of protein and energy. It contains moderate percentage of protein along with high level of fat and low level of crude fiber, being 12.0, 18.1 and 7.6\% on DM basis, respectively (Rao and Reddy, 1986). So, it is expected that rice polishings is a suitable source of both protein and energy to be included in the diets of farm animals due to its cheap price compared with the traditional feedstuffs as well as other concentrate feed mixtures.

Issued by The Egyptian Society of Animal Production 
The objective of this study was to investigate the effect of inclusion of rice polishings in daily ration of Ossimi lambs to partly replace a conventional concentrate feed mixture at different levels on growth performance, nutrients digestibilities and carcass traits in order to reduce feed cost.

\section{MATERIALS AND METHODS}

This study was carried out at El-Hussein village, west of Nubaria, El-Behera Governorate, Egypt and the laboratories of Animal and Poultry Nutrition and Production Department, National Research Centre, Dokki, Cairo.

Twenty-one Ossimi male lambs, 5-6 months old with average weight of $30.11 \mathrm{~kg}$, were used in a feeding trial lasted for 16 weeks. Animals were divided into three similar groups according to age and weight. Lambs from each group were assigned randomly to one of the following three experimental rations.

Ration 1 (control, T1) consisted of a conventional concentrate feed mixture plus groundnut hay (as a source of roughage) while rations 2 (T2) and 3 (T3) consisted of the same ingredients of the control but 30 and $60 \%$ respectively of the concentrate feed mixture was replaced by rice polishings (RP). Groundnut hay was offered ad libitum once daily at 02:00 p.m. while the concentrate portion of each animal was fed at a rate of $3 \%$ of live body weight divided into two equal parts, offered at 08:00 a.m. and $02: 00$ p.m. respectively. The composition of the experimental rations are presented in table 1 . The chemical composition of different experimental feed stuffs are presented in table 2 .

Table 1. Composition of the experimental rations

\begin{tabular}{lccc}
\hline & & \multicolumn{3}{c}{ Rations } \\
\cline { 2 - 4 } Ingredient, \% & $\mathrm{T} 1$ & $\mathrm{~T} 2$ & $\mathrm{~T} 3$ \\
& Control & $30 \% \mathrm{RP}$ & $60 \% \mathrm{RP}$ \\
\hline CFM* & 71.25 & 43.81 & 21.99 \\
Rice Polishings & 0.00 & 18.77 & 32.98 \\
Groundnut hay & 28.75 & 37.42 & 45.03 \\
\hline
\end{tabular}

* CFM $=$ concentrate feed mixture, consisting of (as fed): $25 \%$ Sunflower meal, $30 \%$ wheat bran, $22 \%$ ground yellow corn, $12 \%$ chopped berseem hay, $8 \%$ chopped berseem straw, $2 \%$ limestone and $1 \%$ sodium chloride.

Table 2. Chemical composition of different experimental feedstuffs

\begin{tabular}{lccccccc}
\hline \multirow{2}{*}{ Feedstuff } & DM, \% & \multicolumn{6}{c}{ DM Composition, \% } \\
\cline { 3 - 8 } & & OM & Ash & CP & CF & EE & NFE \\
\hline CFM & 88.61 & 91.95 & 8.05 & 15.53 & 14.83 & 2.50 & 59.09 \\
Rice polishings & 91.01 & 91.85 & 8.15 & 13.70 & 7.50 & 15.67 & 54.98 \\
Groundnut hay & 91.01 & 84.54 & 15.46 & 11.34 & 20.05 & 2.18 & 50.97 \\
Ration I & 89.29 & 89.82 & 10.18 & 14.33 & 16.33 & 2.41 & 56.76 \\
Ration II & 89.95 & 89.16 & 10.84 & 13.62 & 15.39 & 4.87 & 55.28 \\
Ration III & 90.47 & 88.59 & 11.41 & 13.04 & 14.76 & 6.71 & 54.08 \\
\hline
\end{tabular}

Animals were individually fed and the daily residues of feed stuffs were removed and weighed. Animals were weighed bi-weekly after $12 \mathrm{~h}$ fasting period, then, daily allowances of concentrate portion were adjusted according to change in live weight. 
At the end of the experiment three lambs from each group were chosen randomly to conduct a digestion trial for estimating nutrients digestibilities, feeding values and nitrogen balance. Animals were placed in metabolic cages for ten days as a preliminary period, followed by seven days collection period.

The remainder four lambs of each group were slaughtered after $18 \mathrm{~h}$ fasting period. Following slaughter and removing the pelt, the offals, thoracic and abdominal organs were removed and weighed. The contents of the digestive tract were also removed and their weight was subtracted from the slaughter live weight to obtain empty body weight. Weights of hot carcass (HCW, including edible organs and tail fat) and fat (tail, omentum and kidney) were recorded and dressing percentages based on fasting and empty body weights were calculated. Carcasses were split into fore and hind quarters between the $12^{\text {th }}$ and $13^{\text {th }}$ ribs and weighed.

The 9,10 and $11^{\text {th }}$ rib section was removed from both sides and was physically dissected into lean, fat and bone tissues which were separately weighed. "Coefficient of meat" (meat included fat: bone ratio was determined).

Feedstuffs, feces, urine and meat were chemically analyzed according to A.O.A.C. methods (1990).

Data were analyzed using general linear procedure of SAS (1995), while Duncan Multiple Range Test (Duncan, 1955) was applied to compare the means.

\section{RESULTS AND DISCUSSION}

No health problems were noticed for all animals on the different experimental diets throughout the entire experimental period.

Data of growth performance (Table 3) indicated that lambs fed on the control ration (group 1) tended to surpass those fed on ration $2(30 \% \mathrm{RP})$ in weight gain, average daily gain (ADG) and growth rate expressed as percentage of initial body weight $(P>0.05)$. At the same time lambs of groups 1 and 2 surpassed $(P<0.05)$ those of group $3(60 \% \mathrm{RP})$ in the same above mentioned parameters with differences between group 1 and group 3 reached $40 \%$ for each of the previous parameters. This superiority of the control on the other groups may be attributed to similar trend found in nutrient digestibilities, nitrogen retention and nutritive values of the rations expressed as TDN and DCP, (Tables 5 and 6). With the higher values, it was expected that lambs fed on the control diet could retain more $\mathrm{N}$ and grow faster.

The present results agree well with those of Alvarez et al. (1981) who found an insignificant decrease in daily gain of calves with diet containing rice polishings ( $700 \mathrm{~g}$ daily) compared with another one containing chopped immature green bananas ( $7.5 \mathrm{~kg}$, daily) (423 g vs $445 \mathrm{~g}$ respectively). Similarly, Llamas-Lamas et al. (1985) found that daily weight gain was not significantly different among groups of steers given untreated wheat straw or straw injected with ammonia without or with $30 \%$ sorghum or rise polishings. On the other hand, Albuernes et al. (1992) reported a decrease in mean daily gain of lambs when $10 \%$ rice polishings was fed as starch supplement compared with $10 \%$ rice bran or $20 \%$ wheat bran in diets based on chopped whole sugarcane with $3 \%$ urea.

It is clear from table 4 that DM intake of dietary concentrate portion (CFM + RP) was decreased with increasing RP levels, meanwhile, the intake from ground nut hay was increased. These results are in accordance with those of Cardenes et al. (1993) who reported a reduction in grass hay DM intake by sheep when fed with RP instead 


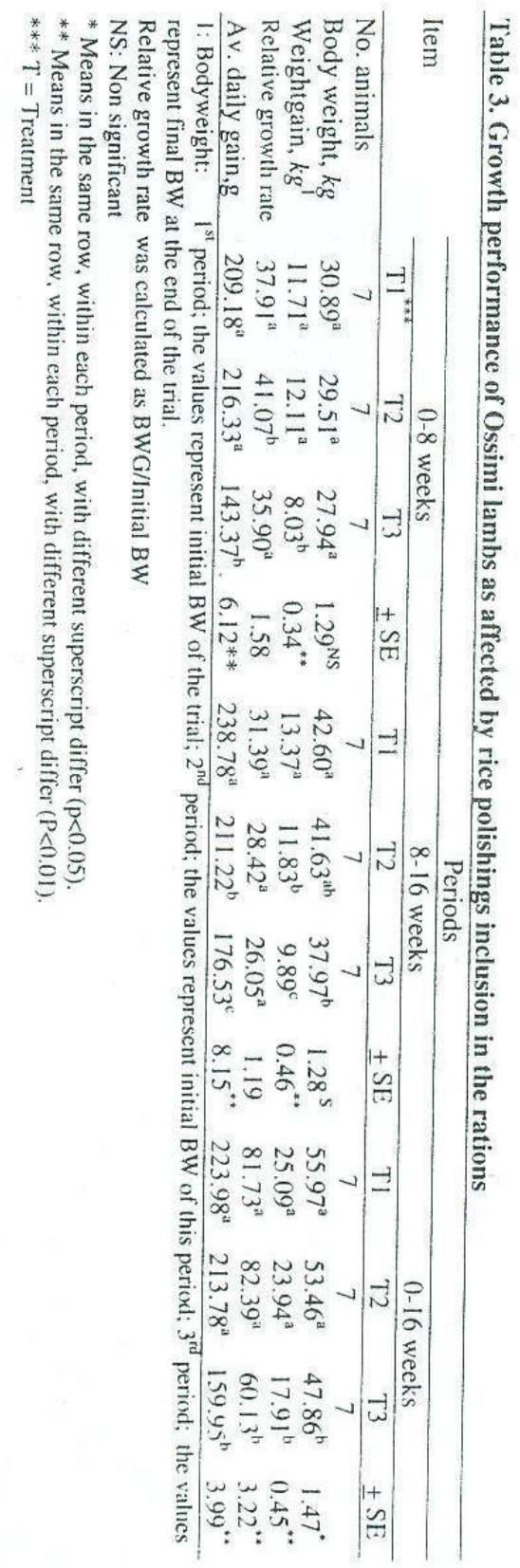




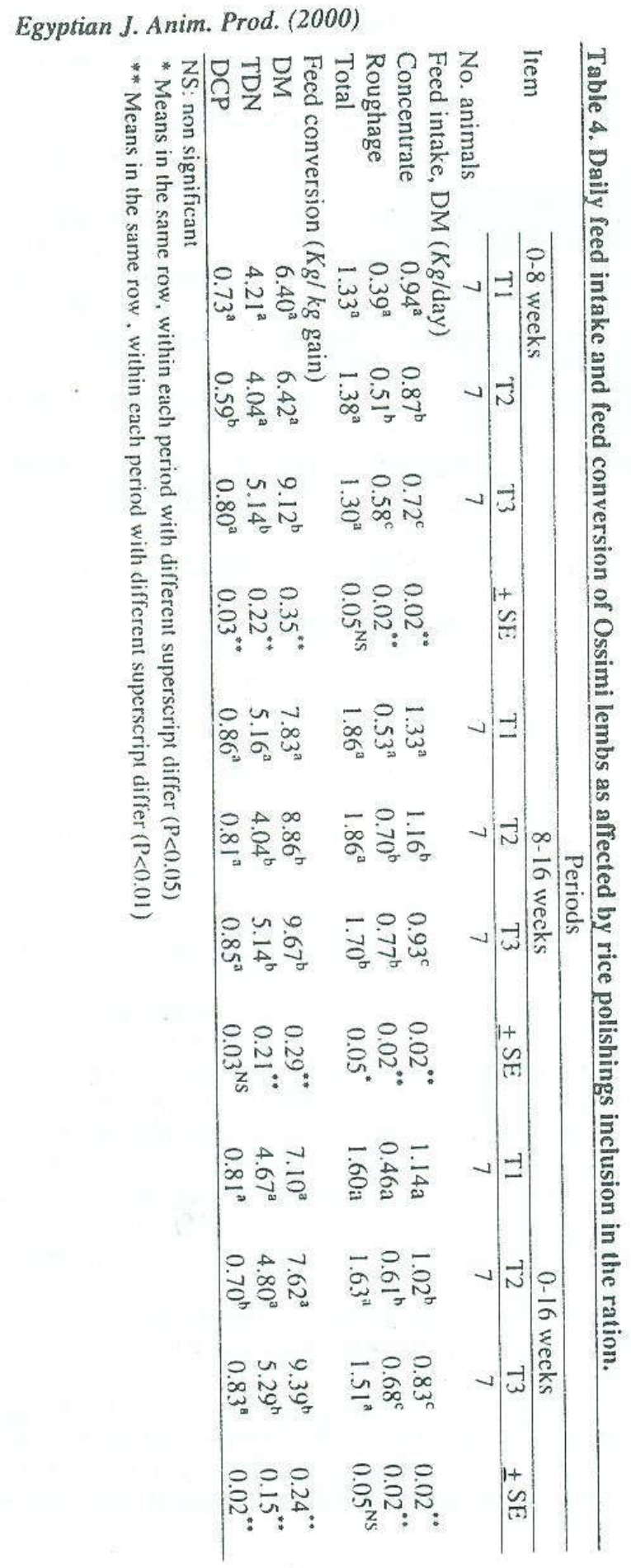


of urea sugarcane molasses. Voluntary intake of grass hay was reduced in diets supplemented with RP (Cardenas et al., 1993).

Lambs on the high RP diets (Table 4) converted feed DM and energy (TDN) less efficiently $(P<0.05)$ than those on the control or low RP diets which were similar. However, DCP conversion value was the best with lambs on $30 \% \mathrm{RP} \operatorname{diet}(\mathrm{P}<0.05)$ when compared with the control and those on $60 \%$ RP diets being similar.

The inspection of nutrients digestibilities of the tested rations (Table 5) showed an obvious decrease in each of OM, CP, EE and NFE digestibilities with RP feeding. The decrease was much greater with the high level of RP (OM and NFE digestibilities). On the other hand, CF digestibility was depressed with the high level of RP in the ration $(60 \%)(\mathrm{P}<0.05)$. The decrease in nutrient digestibilities of RP diets lowered the nutritive values of these diets expressed as TDN and DCP.

Table 5. Digestibility coefficients and feeding values of experimental rations

\begin{tabular}{|c|c|c|c|c|}
\hline \multirow[t]{2}{*}{ Item } & \multicolumn{4}{|c|}{ Treatments } \\
\hline & $\begin{array}{c}\mathrm{T}_{1} \\
\text { (control) }\end{array}$ & $\begin{array}{c}\mathrm{T}_{2} \\
(30 \% \mathrm{RP})\end{array}$ & $\begin{array}{c}\mathrm{T}_{3} \\
(60 \% \mathrm{RP})\end{array}$ & $\pm S E$ \\
\hline \multirow[t]{2}{*}{ No. of animals } & 3 & 3 & 3 & \\
\hline & \multicolumn{2}{|c|}{ Digestibility coefficient, $\%$} & & \\
\hline OM & $70.64^{a}$ & $66.54^{a b}$ & $63.68^{b}$ & $1.72^{* 0}$ \\
\hline $\mathrm{CP}$ & $79.19^{\mathrm{a}}$ & $66.14^{b}$ & $65.04^{b}$ & $1.92^{*}$ \\
\hline CE & $48.50^{a}$ & $52.75^{\mathrm{a}}$ & $28.58^{b}$ & $2.90^{*}$ \\
\hline EE & $73.83^{\mathrm{a}}$ & $61.98^{b}$ & $59.65^{b}$ & $1.14^{* *}$ \\
\hline NFE & $74.71^{\mathrm{a}}$ & $69.69^{\mathrm{a}}$ & $59.52^{b}$ & $1.99^{\circ *}$ \\
\hline \multicolumn{5}{|l|}{ Feeding Values, $\%$} \\
\hline TDN & $65.82^{2}$ & $63.02^{b}$ & $56.59^{\mathrm{c}}$ & $1.73^{* *}$ \\
\hline DCP & $11.35^{\mathrm{a}}$ & $9.13^{b}$ & $8.79^{c}$ & $0.23^{* * *}$ \\
\hline
\end{tabular}

NS $=$ Non significant

*: Means in the same row with different superscripts significantly differ $(\mathrm{P}<0.05)$

**: Means in the same row with different superscripts significantly differ $(\mathrm{P}<0.01)$

Results of nitrogen balance (NB), (Table 6) revealed that nitrogen intake (NI) was highest with the control animals and decreased with each increase in level of RP in the diets $(\mathrm{P}<0.05)$. This is attributed to the decrease in $\mathrm{CP} \%$ of ration 2 and 3 containing RP along with the decrease in DM intake (Tables 2 and 4 ).

Fecal (F) and Urinary (U) N decreased with increasing RP\% in the rations. This reflected the decrease in NI rather than better performance, since when the values of $(\mathrm{PN}+\mathrm{UN})$ was related to NI, the values increased $(\mathrm{P}<0.05)$ with increasing percentage RP in the rations. All the above- mentioned values resulted in poor $\mathrm{N}$ batance for rations containing RP expressed as $\mathrm{N}$ retained when compared with the antrol.

In General, the decrease in the performance i.e growth, feed conversion and nutrients digestibilities, associate RP feeding particularly at $60 \%$ level (ration 3 ) may be explained in the following points:

The high starch content of RP (258 g/ $\mathrm{kg} \mathrm{DM})$ for full-fat RP and the rapid degradation of this starch within the rumen stimulate VFA production particularly with the inclusion of high levels in the diets (Cardenas et al. 1992). Also, Rathee and Lohan (1988) reported that the protein of RP was extensively degraded in the rumen. 
Egyptian J. Anim. Prod. (2000)

Cardenas et al. (1993) found low microbial protein yield when RP was given, and they also reported that the supply to the rumen of $\mathrm{N}$ and fermentable energy from $\mathrm{RP}$ was less well synchronized, since with RP ammonia concentration peaked $1 \mathrm{~h}$ after feeding but VFA concentration were still rising $6 \mathrm{~h}$ after feeding.

Table 6. Nitrogen balance of Ossimi lambs as affected by rice polishing inclusion

\begin{tabular}{lcccc}
\multicolumn{4}{c}{ in the rations } & \multicolumn{4}{c}{ Treatments } \\
\cline { 2 - 5 } & $\begin{array}{c}\mathrm{T}_{1} \\
\text { (control) }\end{array}$ & $\begin{array}{c}\mathrm{T}_{2} \\
(30 \% \mathrm{RP})\end{array}$ & $\begin{array}{c}\mathrm{T}_{3} \\
(60 \% \mathrm{RP})\end{array}$ & $\pm \mathrm{SE}$ \\
\hline No of animals & 3 & 3 & 3 & \\
Nitrogen balance (g/day) & & & & \\
Intake (I) & $34.85^{\mathrm{a}}$ & $30.93^{\mathrm{b}}$ & $23.62^{\mathrm{c}}$ & $0.97^{* *}$ \\
Feacal (F) & $8.11^{\mathrm{a}}$ & $8.03^{\mathrm{a}}$ & $5.64^{\mathrm{b}}$ & $0.46^{*}$ \\
Urinary (U) & $19.86^{\mathrm{a}}$ & $17.13^{\mathrm{b}}$ & $13.73^{\mathrm{c}}$ & $0.62^{* *}$ \\
Retained (R) & $6.88^{\mathrm{a}}$ & $5.78^{\mathrm{a}}$ & $4.26^{\mathrm{b}}$ & $0.34^{* *}$ \\
NR\% from NI & $14.33^{\mathrm{a}}$ & $13.81^{\mathrm{b}}$ & $13.51^{\mathrm{c}}$ & $0.00^{* *}$ \\
(UN + FN) \% from NI & $2.62^{\mathrm{a}}$ & $5.19^{\mathrm{b}}$ & $8.34^{\mathrm{c}}$ & $0.00^{* *}$ \\
\hline
\end{tabular}

*: Means in the same row with different superscript significantly differ $(\mathrm{P}<0.05)$

**: Means in the same row with different superscript significantly differ $(\mathrm{P}<0.01)$

On the other hand, it was reported that fat in the rumen appears to inhibit fibre degradation (Harfoot, 1974), and may be toxic to cellulolytic bacteria (El-Hag and Miller, 1972). The high concentration of fat in RP might therefore be expected to lead to a reduction in dietary intake as suggested by Devendra and Lewis (1974). The high lipid concentration of RP, mainly in the form of oleic, linoleic and palmitic acids which accounted proportinately for over $96 \%$ (by weight) of total fatty acids (Cardenas et al., 1993) are recognized to have antibacterial effect (Colman, 1980). Also, lipids have been shown to inhibit the growth of rumen protozoa (Broudiscou, 1990).

On the other hand, other workers have observed little or no effect on the rumen fermentation in vivo of including RP at up to $250 \mathrm{~g} / \mathrm{kg}$ diet (Ferreiro et al., 1979 and Valdez et al., 1977).

Also the increase in groundnut hay with increasing \% RP in the rations may involve in lack of performance particularly with ration 3 .

It is clear from data presented in Table 7 that fasting and empty body weights were heavier with the control lambs followed by those on 30\% RP and finally those on high RP level $(\mathrm{P}<0.05)$. Hot carcass weight including edible organs followed similar trend. Omar and Houria (1994) and Houria et al. (1995) reported that carcass weights was increased with body size. Dressing percentages expressed as hot carcass weight based on empty body weight were not affected significantly by different treatments. Neck, fore-quarter and hind-quarter weights were decreased with RP feeding.

Results in table 8 showed that absolute weight of each head, four legs, full digestive tract and empty digestive tract decreased with feeding the high level of RP. This may be due to lower body weight. On the other hand, when weights of four legs and empty digestive tract were related to empty body weight, there were no significant differences among treatments. 
Table 7. Carcass characteristics of Ossimi lambs as affected by level of rice polishings in the rations

\begin{tabular}{|c|c|c|c|c|}
\hline \multirow[t]{2}{*}{ Item } & \multicolumn{4}{|c|}{ Treatments } \\
\hline & $\begin{array}{c}\mathrm{T}_{1} \\
\text { (control) }\end{array}$ & $\begin{array}{c}\mathrm{T}_{2} \\
(30 \% \mathrm{RP})\end{array}$ & $\begin{array}{c}\mathrm{T}_{3} \\
(60 \% \mathrm{RP}) \\
\end{array}$ & $\pm \mathrm{SE}$ \\
\hline No of carcasses & 4 & 4 & 4 & \\
\hline Fasting body weight, $\mathrm{kg}$ & $54.20^{\mathrm{a}}$ & $51.30^{\mathrm{a}}$ & $43.30^{6}$ & $1.00^{* *}$ \\
\hline Empty body weight, kg & $42.40^{\mathrm{a}}$ & $39.60^{\mathrm{b}}$ & $35.33^{\mathrm{c}}$ & $0.78^{* * *}$ \\
\hline Hot carcass weight, $\mathrm{kg}$ & $25.84^{\mathrm{a}}$ & $23.69^{a}$ & $20.37^{b}$ & $0.77^{* *}$ \\
\hline Dressing, $\%^{1}$ & $47.68^{\mathrm{a}}$ & $46.18^{a}$ & $47.04^{\mathrm{a}}$ & $0.99^{\mathrm{NS}}$ \\
\hline Dressing, $\%^{2}$ & $60.94^{\mathrm{a}}$ & $59.82^{\mathrm{a}}$ & $57.66^{\mathrm{a}}$ & $1.92^{\mathrm{NS}}$ \\
\hline Neck, kg & $1.99^{\mathrm{a}}$ & $1.68^{\mathrm{ab}}$ & $1.36^{\mathrm{b}}$ & $1.45^{*}$ \\
\hline$\%^{3}$ & $7.31^{\mathrm{a}}$ & $6.74^{a}$ & $6.29^{a}$ & $0.46^{\mathrm{NS}}$ \\
\hline Fore quarter, kg & $11.70^{\mathrm{a}}$ & $11.38^{\mathrm{a}}$ & $9.45^{b}$ & $0.24^{* *}$ \\
\hline$\%^{3}$ & $43.21^{\mathrm{a}}$ & $45.78^{b}$ & $44.12^{a b}$ & $0.58^{*}$ \\
\hline Hind quarter, $\mathrm{kg}$ & $9.25^{\mathrm{a}}$ & $8.28^{\mathrm{ab}}$ & $7.53^{b}$ & $0.31^{* *}$ \\
\hline$\%^{3}$ & $34.11^{a b}$ & $33.30^{\mathrm{b}}$ & $35.04^{\mathrm{a}}$ & $0.35^{*}$ \\
\hline \multicolumn{5}{|c|}{1, based on fasting weight 2 , based on empty weight } \\
\hline \multirow{2}{*}{\multicolumn{5}{|c|}{$\begin{array}{l}\text { 3. Percentages related to hot carcass weight } \quad \text { NS: non significant } \\
* \text { : Means in the same row with different superscript significantly differ }(\mathrm{P}<0.05)\end{array}$}} \\
\hline & & & & \\
\hline **: Means in the same & & signifi & $r(P<0.0$ & \\
\hline
\end{tabular}

Kidney and test weights were not affected significantly by treatments while, weights of liver and lungs were decreased with the high RP level.

Each of omentum, kidney and tail fat weights decreased with the high level of RP compared with the control or low RP diets $(\mathrm{P}<0.05)$. Also it is clear that separable fat weights either as absolute or relative values to hot carcass weights were decreased with RP feeding. Relative differences of absolute separable fat weights between the control and those of groups 2 and 3 were 19.9 and $42.9 \%$, respectively. The corresponding differences in relative separable fat to hot carcass among the same respective groups were only 10.8 and $13.8 \%$.

The physical analysis of best ribs cut (Table 9) showed that lambs fed on RP had less lean, fat and bone weights, however when these values were expressed as percentages, there were no significant differences to be detected among different groups. Bonless meat \% and lean/fat ratio were not affected by treatments.

Regarding the chemical analysis of meat (table 9), it was obvious that RP feeding did not affect significantly moisture, protein, ether extract or ash percentage

The data of economic efficiency as affected by inclusion of rice polishings in the rations are presented in table 10. Despite of lower price of rice polishings as compared with that of CFM which is reflected on lowering feed cost, the economical efficiency was decreased with $60 \% \mathrm{RP}$ inclusion in the diets (group 3 ) as a reflection of lowering weight gain (Table 3). On the other hand, inclusion of RP in the rations at $30 \%$ level positively affected the economic efficiency as compared with those of the control due to lowering feed cost without affecting weight gain. Relative sconomic efficiency related to that of the control followed the same trend.

It could be concluded that inclusion of rice polishing in the rations of Ossimi lambs to replace up to $30 \%$ of the conventional concentrate feed mixture did not 
Egyptian J. Anim. Prod. (2000)

show marked negative effect on ADG, feed conversion, quantity and quality of produced meat.

Table 8. Offals of slaughtered Ossimi lambs as affected by level of rice polishings in the rations

\begin{tabular}{|c|c|c|c|c|}
\hline \multirow[t]{2}{*}{ Item } & \multicolumn{4}{|c|}{ Treatments } \\
\hline & $\begin{array}{c}\mathrm{T}_{1} \\
\text { (control) }\end{array}$ & $\begin{array}{c}\mathrm{T}_{2} \\
(30 \% \mathrm{RP})\end{array}$ & $\begin{array}{c}\mathrm{T}_{3} \\
(60 \% \mathrm{RP})\end{array}$ & $\pm \mathrm{SE}$ \\
\hline Fasting body weight, $\mathrm{kg}$ & $54.20^{\mathrm{a}}$ & $51.30^{\mathrm{a}}$ & $43.30^{b}$ & $1.00^{* * 2}$ \\
\hline Hot carcass weight, $\mathrm{kg}$ & $25.84^{\mathrm{a}}$ & $23.69^{a}$ & $20.37^{\mathrm{b}}$ & $0.77^{* *}$ \\
\hline Head, $\mathrm{kg}$ & $3.85^{\mathrm{a}}$ & $4.15^{\mathrm{a}}$ & $2.89^{b}$ & $0.18^{* *}$ \\
\hline$\%^{1}$ & $7.10^{\mathrm{a}}$ & $8.09^{b}$ & $6.66^{\mathrm{a}}$ & $0.28^{*}$ \\
\hline Pelt, kg & $4.91^{\mathrm{a}}$ & $4.19^{\mathrm{a}}$ & $4.59^{\mathrm{a}}$ & $0.30^{\mathrm{NS}}$ \\
\hline$\%^{1}$ & $9.08^{\mathrm{ab}}$ & $8.18^{a}$ & $10.63^{b}$ & $0.67^{\mathrm{NS}}$ \\
\hline Four legs, $\mathrm{kg}$ & $1.26^{\mathrm{a}}$ & $1.31^{\mathrm{a}}$ & $1.01^{\mathrm{b}}$ & $0.06^{*}$ \\
\hline$\%^{1}$ & $2.33^{a}$ & $2.55^{\mathrm{a}}$ & $2.35^{\mathrm{a}}$ & $0.14^{\mathrm{NS}}$ \\
\hline Full digestive tract, $\mathrm{kg}$ & $15.70^{\mathrm{a}}$ & $15.70^{\mathrm{a}}$ & $11.45^{b}$ & $0.48^{* *}$ \\
\hline$\%^{1}$ & $28.96^{\mathrm{a}}$ & $30.63^{a}$ & $26.41^{b}$ & $0.71^{* *}$ \\
\hline Empty digestive tract, $\mathrm{kg}$ & $3.90^{\mathrm{a}}$ & $4.00^{\mathrm{a}}$ & $3.48^{a}$ & $0.25^{* 8}$ \\
\hline$\%^{1}$ & $7.19^{\mathrm{a}}$ & $7.81^{\mathrm{a}}$ & $8.05^{\mathrm{a}}$ & $0.61^{\mathrm{NS}}$ \\
\hline Liver, $\mathrm{g}$ & $833^{\mathrm{a}}$ & $868^{a}$ & $748^{\mathrm{b}}$ & $24^{*}$ \\
\hline Heart, $g$ & $290^{\mathrm{a}}$ & $190^{b}$ & $210^{\mathrm{b}}$ & $9^{* *}$ \\
\hline Lungs, $g$ & $575^{\mathrm{ab}}$ & $658^{a}$ & $510^{b}$ & $32^{*}$ \\
\hline Kidneys, g & $138^{\mathrm{a}}$ & $135^{\mathrm{a}}$ & $128^{a}$ & $5^{\mathrm{NS}}$ \\
\hline Spleen, g & $60^{\mathrm{a}}$ & $83^{b}$ & $55^{\mathrm{a}}$ & $5^{* *}$ \\
\hline Testes, $\mathrm{g}$ & $270^{a}$ & $265^{\mathrm{a}}$ & $245^{\mathrm{a}}$ & $25^{\mathrm{NS}}$ \\
\hline Omentum fat, $g$ & $133^{a}$ & $150^{\mathrm{a}}$ & $95^{b}$ & $7^{* *}$ \\
\hline Kindey fat, $g$ & $103^{x}$ & $105^{a}$ & $58^{\mathrm{b}}$ & $5^{* *}$ \\
\hline Tail fat, $\mathrm{kg}$ & $2.90^{\mathrm{a}}$ & $2.35^{a b}$ & $2.04^{b}$ & $0.182^{*}$ \\
\hline$\%^{2}$ & $10.71^{a}$ & $9.40^{\mathrm{a}}$ & $9.47^{\mathrm{a}}$ & $0.55^{\mathrm{NS}}$ \\
\hline Separable fat, $\mathrm{kg}$ & $3.13^{\mathrm{a}}$ & $2.61^{\mathrm{ab}}$ & $2.19^{\mathrm{b}}$ & $0.19^{*}$ \\
\hline$\%^{2}$ & $11.56^{\mathrm{a}}$ & $10.43^{\mathrm{a}}$ & $10.16^{\mathrm{a}}$ & $0.57^{\mathrm{NS}}$ \\
\hline Edible organs, $\mathrm{kg}$ & $1.26^{\mathrm{a}}$ & $1.19^{\mathrm{a}}$ & $1.09^{\mathrm{b}}$ & $0.03^{* *}$ \\
\hline$\%^{2}$ & $4.67^{a}$ & $4.78^{\mathrm{a}}$ & $5.08^{\mathrm{a}}$ & $0.19^{\mathrm{NS}}$ \\
\hline
\end{tabular}

1: Percentages related to empty body weight.

2: Percentages related to hot carcass weight.

NS: non significant

*: Means in the same row with different superscripts significantly differ $(\mathrm{P}<0.05)$

**: Means in the same row with different superscripts differ $(\mathrm{P}<0.01)$ 
Table 9. Physical and chemical composition of best ribs cut $\left(9-10-11^{\text {th }}\right)$ of slaughtered Ossimi lambs fed different levels of rice polishings

\begin{tabular}{lcccc}
\hline Item & $\begin{array}{c}\mathrm{T}_{1} \\
\text { (control) }\end{array}$ & $\begin{array}{c}\mathrm{T}_{2} \\
(30 \% \mathrm{RP})\end{array}$ & $\begin{array}{c}\mathrm{T}_{3} \\
(60 \% \mathrm{RP})\end{array}$ & $\pm \mathrm{SE}$ \\
\hline No. of ribs cut & 4 & 4 & 4 & \\
Physical components & & & & \\
Lean (L) weight, g & $538.25^{\mathrm{a}}$ & $429.50^{\mathrm{b}}$ & $477.75^{\mathrm{ab}}$ & $26.48^{*}$ \\
& 55.08 & 54.54 & 54.11 & $0.69^{\mathrm{NS}}$ \\
Fat (F) weight, g & 236.75 & 206.75 & 217.00 & $14.71^{\mathrm{NS}}$ \\
& 24.16 & 26.24 & 24.61 & $0.82^{\mathrm{NS}}$ \\
Bone (B) weight, g & $202.50^{\mathrm{a}}$ & $151.25^{\mathrm{b}}$ & $187.75^{\mathrm{a}}$ & $8.88^{* \mathrm{~b}}$ \\
& $20.76^{\mathrm{ab}}$ & $19.23^{\mathrm{a}}$ & $21.28^{\mathrm{b}}$ & $0.49^{*}$ \\
Bonless meat \% & $79.24^{\mathrm{ab}}$ & $80.77^{\mathrm{a}}$ & $78.73^{\mathrm{b}}$ & $0.49^{*}$ \\
L/F ratio & 2.28 & 2.09 & 2.21 & $0.1^{\mathrm{NS}}$ \\
L/B ratio & $2.67^{\mathrm{ab}}$ & $2.84^{\mathrm{a}}$ & $2.54^{\mathrm{b}}$ & $0.07^{*}$ \\
Coefficient of meat & $3.84^{\mathrm{a}}$ & $4.20^{\mathrm{b}}$ & $3.70^{\mathrm{a}}$ & $0.11^{*}$ \\
Chemical composition, \% from fresh weight & & & \\
Moisture & 57.68 & 57.36 & 57.26 & $0.85^{\mathrm{NS}}$ \\
Protein & 19.15 & 20.29 & 20.65 & $0.51^{\mathrm{NS}}$ \\
Ether Extract & 22.03 & 21.15 & 20.98 & $0.77^{\mathrm{NS}}$ \\
Ash & 1.17 & 1.20 & 1.11 & $0.06^{\mathrm{NS}}$ \\
\hline
\end{tabular}

$1 \cdot L+F / B$ ratio, NS: non significant

*: Means in the same row with different superscripts significantly differ $(\mathrm{P}<0.05)$

**: Means in the same row with different superscripts significantly differ $(P<0.01)$

Table 10. Economic efficiency as affected by inclusion of rice polishings in the diets of Ossimi male lambs

\begin{tabular}{|c|c|c|c|}
\hline \multirow[t]{2}{*}{ fiem } & \multicolumn{3}{|c|}{ Experimental group } \\
\hline & $\mathrm{T} 1$ (Control) & $\mathrm{T} 2(30 \% \mathrm{RP})$ & $\mathrm{T} 3(60 \% \mathrm{RP})$ \\
\hline \multicolumn{4}{|l|}{ Total DM intake /lamb from } \\
\hline CFM & 126.84 & 79.53 & 36.95 \\
\hline RP & 0.00 & 34.42 & 55.44 \\
\hline Groundnut hay & 51.18 & 67.99 & 75.48 \\
\hline Total feed cost/lamb, L. $E^{1}$ & 94.09 & 75.41 & 54.80 \\
\hline Initial bc ky weight, $\mathrm{kg}$ & 30.89 & 29.51 & 29.94 \\
\hline Final body weight, kg & $55: 97$ & 53.46 & 47.86 \\
\hline Fixed cost/lamb, L.E. ${ }^{2}$ & 278.01 & 265.59 & 269.46 \\
\hline Management/lamb, L.E. ${ }^{3}$ & 50 & 50 & 50 \\
\hline Tal costlamb, L.E. ${ }^{4}$ & 422.1 & 391 & 374.26 \\
\hline Selling income/lamb, L.E $E^{5}$. & 503.73 & 481.14 & 430.74 \\
\hline Net revenue/lamb, L.E & 81.63 & 90.14 & 56.48 \\
\hline 3: onomic efficiency ${ }^{6}$ & 0.193 & 0.231 & 0.151 \\
\hline K lative economical efficiency, $\%^{7}$ & 100 & 120 & 78 \\
\hline \multicolumn{4}{|c|}{$\begin{array}{l}\text { F ices of ton of CFM, RP and Groundnut hay were L.E. } 540,120 \text { and } 300 \text {, respectively where } \\
1.3=88.61,91.01 \text { and } 91.01 \% \text {, respectively. Body weight } x \text { price of } 1 \mathrm{~kg} \text { (L.E). } \\
\text { Include medication, vaccines and sanitation., Include the fixed cost }+ \text { management }+ \text { feed cost. } \\
\text { Body weight } x \text { price of } 1 \mathrm{~kg} \text { at selling which was } L . E 9 \text {. Net revenue per unit of total cost. } \\
\text { Acsuning that relative economical efficiency of the control group equals } 100 \text {. }\end{array}$} \\
\hline
\end{tabular}




\section{REFERENCES}

A.O.A.C., 1990. Official Methods of Analysis. $15^{\text {th }}$ ed., Assos. Offic. Agric. Chemists, Washington, D.C., USA.

Albuernes, R.; A. Perera and N. Peron, 1992. Considerations on the use of feeds containing starch in diets with whole chopped sugarcane in the feeding of sheep. Revista. Cubana de Reproduction Animal. No. Especial, 77-92.

Alvarez, F.J., G. Savcedo and A. Arriga, 1981. Obervations on performance of calves reared by restricted suckling and supplemented with either rice polishings or green banans. Tropical Animal production, $6: 285$.

Broudiscow, L., C.L. Van Nevel and D.I. Demeyer, 1990. Effect of soya oil hydrolysate on rumen digestion in defaunated and refaunated sheep. Animal Feed Science and Technology 30: 51-67.

Cardenas, G.D.; C.J. Newbold; H. Guibraith; J.H. Topps, 1992. The effect of including colombian rice polishings in the diet on rumen fermentation in vitro. Animal Production, $54: 275-280$.

Cardenas Garcia, D.; C.J. Newbold; H. Gaibraith; J.H. Topps; X.B., Chen and A.J. Rooke, 1993.. Rice polishings as an alternative to sugar cane molasses as a supplement with urea to low-quality forage diets for ruminants. Animal Production, 56(1): 85 - 92.

Colman, G.S., 1980. Rumen ciliate protozoa. In advances in Parasitology, Vol. 18 fed. W.H.R. Lumsden, R. Muller, and J.R. Baker), PP. 121-170 Academic Press.

Devendra, C. and D. Lewis, 1974. Fat in ruminant diets: review. Indian Journal of Animal Science 44: 917-938.

Duncan, D.B., 1955. Multiple range and multiple F test. Biometeric 11.1

El-Banna, H.M., 1993. Effect of dietary energy, protein and their interaction on nutrient utilization by sheep, goat and camel. Ph.D. Thesis, Faculty of Agriculture, Cairo University.

El-Hag, G.A. and J.B. Miller, 1972. Evaluation of whisky distillery by-products. VI.

interaction with calcium and other reversal agents. Journal of the Science of Food and Agriculture 23: 247-258.

Ferreiro, H.M., A. Priego, J. Lopez, T.R. Preston and R.A. Leng, 1979. Glucose metabolism in cattle given sugar cane based diets supplemented with varying quantities of rice polishings. British Journal of Nutrition 42: 341-347.

Harfoot, C.G., M.L. Grouchman, R.C. Noble and J.H. Moore, 1974. Competition between food particles and rumen bacteria in the uptake of long chain fatty acids and triglycerides. Journal of Applied Bacteriology 37: 633-641.

Houria, M.A.; S.S. Omar and T. Abou-Steit, 1995. Effect of castration on some behavioural, growth and carcass traits. Menof ia J. Agric. Res.,20(4): 1481.

Llamas-Lamas , G.; H. Canez-Carrasco; R. Gomez- Alarcon; T. Diaz- Nieblas; H. Romero- Garcia, 1985. Use of ammonia-treated wheat straw in the feeding of growing sheep in feedlots. Tecnica Pecuaria en Mexico. No.48 : 46-53.

Omar, S.S. and M.A. Houria, 1994. A study of some carcass and wool characteristics of culled Ossimi ewes. Egyptian J. Anim. Prod. 31(1): 125. 
Rao, E.P.V. and C.V. Reddy, 1986. Evaluation of chemical and nutrient composition in raw, dc-oiled and parboiled rice polishings and maize. Indian J. of Poultry Sci., 21(1): 72-74.

Rathee, C.S. and O.P. Lohan, 1988. Effect of oil extraction techniques on the nutritive value of deoiled rice bran. Indian J. Anim. Sci. 58: 823-829.

SAS Institute, Inc., 1995. SASI STAT Guide for personal Computers, vers 1.

Valdez, R.E., F.J. Alvarez, H.M. Ferreiro, F. Guerra, J. Lopez, A. Priego, T.H. Blackburn, R.A. Leng and T.R. Preston, 1977. Rumen function in cattle given sugar cane. Tropical Animal production, 2: 260-272.

أستخدام مستويات متدرجة من مخلف تبييض الأرز في علاهق الحملنا الأوسيمى josil

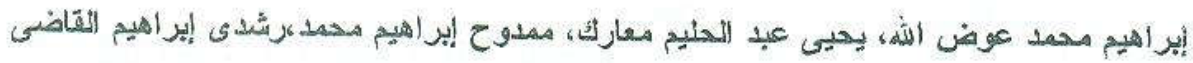
قسم تثذية وإنتاج الحيوان والدواجن المركز القومى للبحوث الدقى القاهرة

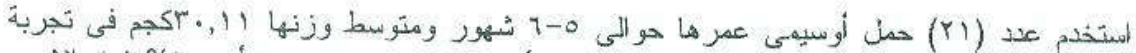

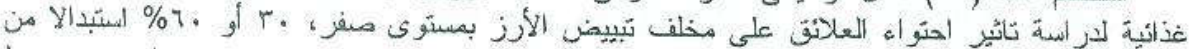

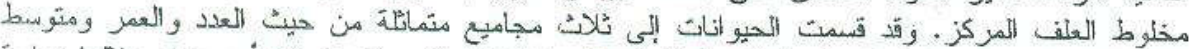

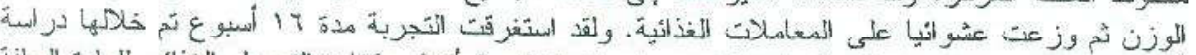

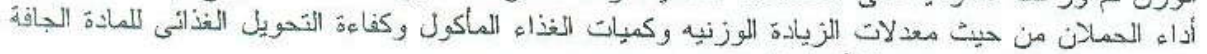

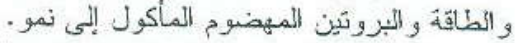

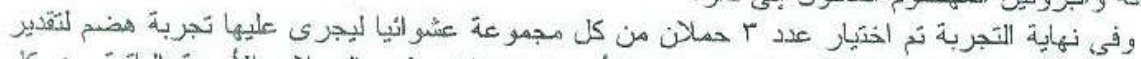

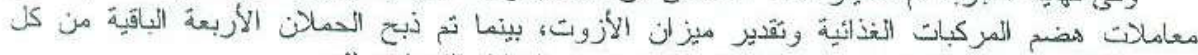

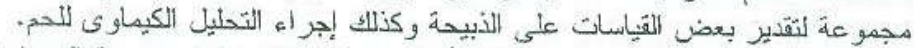

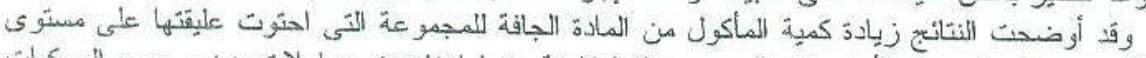

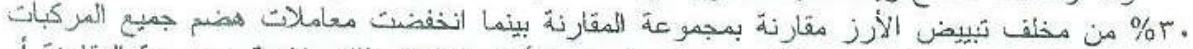

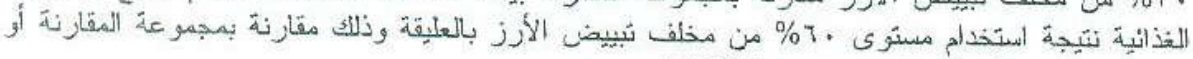

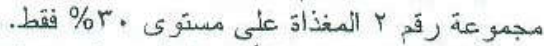

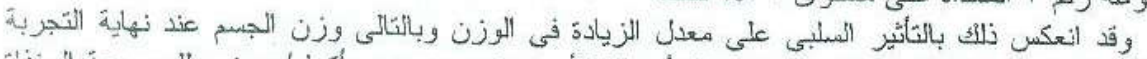

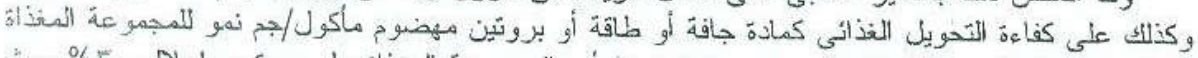

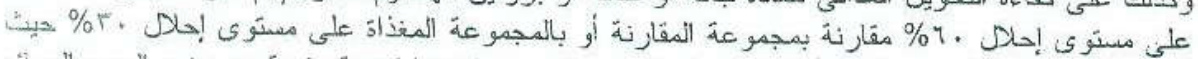

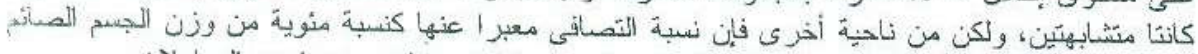

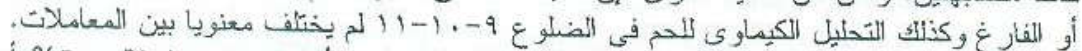

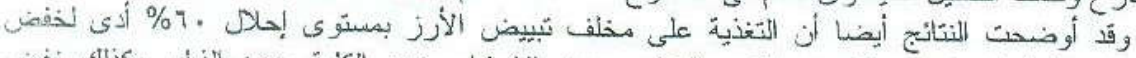

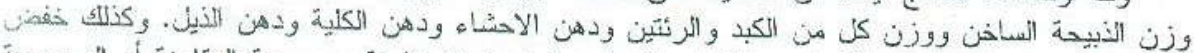

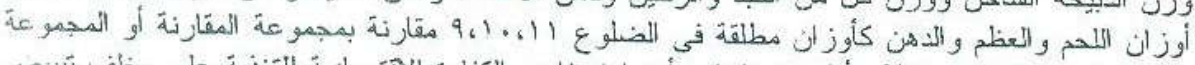

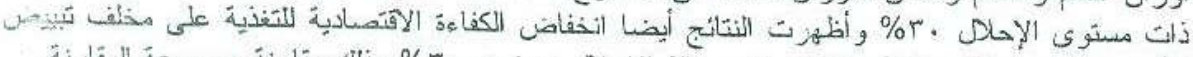

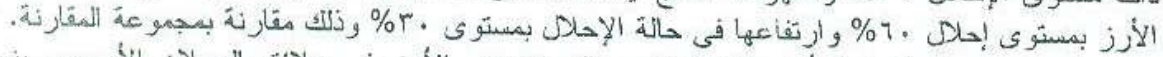

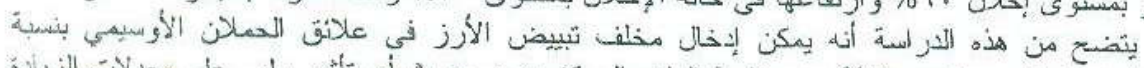

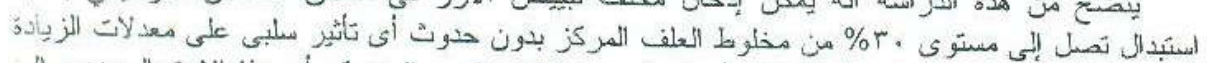

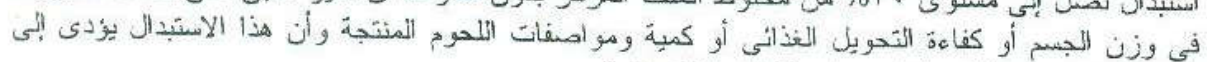
خفضى تكاليف التخذية وبالثالى يرفع الكفاءة الإقتصادية.
} 